\title{
Five Biovars of Yersinia enterocolitica Delineated by Numerical Taxonomy
}

\author{
KEN-ICHI KANEKO AND NOBUO HASHIMOTO \\ Department of Veterinary Public Health, Faculty of Veterinary Medicine, Hokkaido University, Sapporo 060, \\ Japan
}

\begin{abstract}
A total of 52 strains (41 of Yersinia enterocolitica strains, 3 Yersinia pseudotuberculosis strains isolated from animals, and 8 reference strains) were scored for 210 characters (64 morphological, 63 growth, 8 antibiotic susceptibility, and 75 biochemical) which were determined at both 37 and $22^{\circ} \mathrm{C}$. The results were analyzed by numerical taxonomy methods (simple matching coefficients and clustering by unweighted average). The phenograms of the $Y$. enterocolitica strains delineated four and five phenons from the 37 and $22^{\circ} \mathrm{C}$ data, respectively. The phenons at $22^{\circ} \mathrm{C}$ were as follows: (i) rhamnose-negative, lecithinase- and sucrose-positive strains; (ii) rhamnose-, lecithinase-, and sucrose-negative strains; (iii) rhamnose- and lecithinase-negative, sucrose-positive strains; (iv) rhamnose-, lecithinase-, and sucrose-positive strains; and (v) rhamnose-positive, lecithinasenegative, and sucrose-positive strains. These five phenons were designated biovars 1, 2, 3, 4, and 5, respectively. The phenograms of the Y. pseudotuberculosis strains delineated one phenon from both the $37^{\circ} \mathrm{C}$ data and the $22^{\circ} \mathrm{C}$ data. Three sucrose-negative strains of $Y$. enterocolitica had the same deoxyribonucleic acid base composition (guanine-plus-cytosine content) as a strain of serovar $\mathrm{O} 3$ of $Y$. enterocolitica and a strain of serovar IVA of $Y$. pseudotuberculosis.
\end{abstract}

Based on genetic data obtained by deoxyribonucleic acid (DNA)-DNA hybridization, the following four species of Yersinia are currently recognized by Bercovier et al. (3, 4), Brenner (6), Brenner et al. (7, 8), and Ursing et al. (33): Yersinia enterocolitica sensu stricto (rhamnose negative), Yersinia frederiksenii (rhamnose positive), Yersinia intermedia (rhamnose and melibiose positive), and Yersinia kristensenii (sucrose negative). $Y$. enterocolitica is quite heterogenous, both phenetically and genetically, and previously reported work has been aimed at obtaining a more precise delineation of $Y$. enterocolitica $(12,20)$.

$Y$. enterocolitica sensu stricto contains rhamnose- and lecithinase-negative strains, as well as rhamnose-negative, lecithinase-positive strains. The latter are more prevalent in small rodents than the former $(1,2,15,17-19)$. The taxonomic relationships of these strains have been examined in numerical analyses by Harvey and Pickett (12), Kapperud et al. (20), and Stevens and Mair (30). However, numerical taxonomy has not yet been applied to differentiating the rhamnose-negative, lecithinase-positive strains from the strains that are rhamnose and lecithinase negative.

The isolation of sucrose-negative $Y$. enterocolitica strains has been reported in Japan (17), Europe $(2,26)$, Canada (9), and the United
States (5). These strains were found in small rodents $(2,17)$.

The purpose of this study was to determine, by numerical analysis, the taxonomic relationships of the rhamnose- and lecithinase-negative strains and the sucrose-negative strains of $Y$. enterocolitica from small rodents.

\section{MATERIALS AND METHODS}

Bacterial strains. A total of 52 strains (41 Y. enterocolitica strains, 3 Yersinia pseudotuberculosis strains isolated from animals, and 8 reference strains) were examined in this study (Table 1). Of these, the $41 Y$. enterocolitica strains (Table 1, serial no. 5 through 30 and 38 through 52) and $3 Y$. pseudotuberculosis strains (serial no. 31 through 33) were our isolates (14-17). In addition, reference strains of $Y$. enterocolitica (serial no. 1), Y. frederiksenii (serial no. 2), Y. intermedia (serial no. 3), and $Y$. kristensenii (serial no. 4), and four reference strains of $Y$. pseudotuberculosis (serial no. 34 through 37) were studied. Of these, strain 2 was $64 \%$ related to the type strain of $Y$. frederiksenii (strain 6175) based on DNA-DNA hybridization (33). Strain 3 is the type strain of $Y$. intermedia (7). All cultures were maintained frozen at $-80^{\circ} \mathrm{C}$ in equal volumes of calf serum and a $10 \%$ lactose-water solution.

Methods. In determining the morphological characters, the organisms were subcultured on Trypticase soy agar (BBL Microbiology Systems) for 40 to $48 \mathrm{~h}$. Twenty morphological characters based on cell length, width, and shape and eight characters based on cell arrangement were examined by staining the cells with 
TABLE 1. List of strains studied

\begin{tabular}{|c|c|c|c|c|c|c|c|}
\hline \multirow{2}{*}{$\begin{array}{l}\text { Seri- } \\
\text { al } \\
\text { no. }\end{array}$} & \multirow[b]{2}{*}{ Species } & \multicolumn{3}{|c|}{ Biochemical properties $^{a}$} & \multirow{2}{*}{$\begin{array}{c}\text { Strain } \\
\text { designation }\end{array}$} & \multirow[b]{2}{*}{ Source } & \multirow[b]{2}{*}{ Habitat } \\
\hline & & $\begin{array}{l}\text { Rham- } \\
\text { nose }\end{array}$ & $\begin{array}{l}\text { Leci- } \\
\text { thinase }\end{array}$ & $\begin{array}{c}\text { Su- } \\
\text { crose }\end{array}$ & & & \\
\hline 1 & $Y$. enterocolitica & - & - & + & CIP160 & R. Sakazaki & Unknown \\
\hline 2 & $Y$. frederiksenii & + & - & + & YE867 & R. Sakazaki & Unknown \\
\hline 3 & $Y$. intermedia & + & + & + & Bottone no. 48 & R. Sakazaki & Human urine \\
\hline 4 & Y. kristensenii & - & - & - & YE103 & R. Sakazaki & Unknown \\
\hline 5 & $Y$. enterocolitica & - & - & + & $314-2$ & K. Kaneko & Dog \\
\hline 6 & $Y$. enterocolitica & - & - & + & $231-3$ & K. Kaneko & Dog \\
\hline 7 & Y. enterocolitica & - & - & + & $231-4$ & K. Kaneko & Dog \\
\hline 8 & $Y$. enterocolitica & - & - & + & $234-2$ & K. Kaneko & Dog \\
\hline 9 & Y. enterocolitica & + & - & + & M824-2 & K. Kaneko & Brown rat \\
\hline 10 & Y. enterocolitica & + & - & + & M824-1 & K. Kaneko & Brown rat \\
\hline 11 & Y. enterocolitica & + & - & + & ZM433-1 & K. Kaneko & Brown rat \\
\hline 12 & $Y$. enterocolitica & + & - & + & M1245-1 & K. Kaneko & Brown rat \\
\hline 13 & $Y$. enterocolitica & + & - & + & ZS445-1 & K. Kaneko & Brown rat \\
\hline 14 & Y. enterocolitica & + & - & + & ZS564-2 & K. Kaneko & Brown rat \\
\hline 15 & $Y$. enterocolitica & + & + & + & FL-1 & K. Kaneko & Fox \\
\hline 16 & Y. enterocolitica & - & - & + & S1274-5 & K. Kaneko & Brown rat \\
\hline 17 & Y. enterocolitica & - & - & + & S1274-2 & K. Kaneko & Brown rat \\
\hline 18 & Y. enterocolitica & + & + & + & M1226-1 & K. Kaneko & Brown rat \\
\hline 19 & $Y$. enterocolitica & - & - & - & S1096-4 & K. Kaneko & Large red-backed mouse \\
\hline 20 & Y. enterocolitica & - & - & - & M1778-2 & K. Kaneko & Old World wood mouse \\
\hline 21 & Y. enterocolitica & - & - & - & M1779-1 & K. Kaneko & Old World wood mouse \\
\hline 22 & $Y$. enterocolitica & - & - & - & M2200-3 & K. Kaneko & Large red-backed mouse \\
\hline 23 & Y. enterocolitica & - & - & - & $\mathrm{S} 2200-1$ & K. Kaneko & Large red-backed mouse \\
\hline 24 & Y. enterocolitica & - & - & - & M1095-2 & K. Kaneko & Large red-backed mouse \\
\hline 25 & Y. enterocolitica & - & - & - & M1096-1 & K. Kaneko & Large red-backed mouse \\
\hline 26 & $Y$. enterocolitica & - & - & - & S1778-2 & K. Kaneko & Old World wood mouse \\
\hline 27 & Y. enterocolitica & - & - & - & S1779-2 & K. Kaneko & Old World wood mouse \\
\hline 28 & $Y$. enterocolitica & - & - & - & M2200-4 & K. Kaneko & Large red-backed mouse \\
\hline 29 & Y. enterocolitica & - & - & - & M2201-1 & K. Kaneko & Large red-backed mouse \\
\hline 30 & Y. enterocolitica & - & - & - & M2201-4 & K. Kaneko & Large red-backed mouse \\
\hline 31 & Y. pseudotuberculosis & + & - & - & S1186-1 & K. Kaneko & Old World wood mouse \\
\hline 32 & Y. pseudotuberculosis & + & - & - & EM1519-1 & K. Kaneko & Brown rat \\
\hline 33 & Y. pseudotuberculosis & + & - & - & M1909-2 & K. Kaneko & Brown rat \\
\hline 34 & Y. pseudotuberculosis & + & - & - & 377 & M. Tsubokura & Unknown \\
\hline 35 & Y. pseudotuberculosis & + & - & - & 83 & M. Tsubokura & Unknown \\
\hline 36 & Y. pseudotuberculosis & + & - & - & R16 & M. Tsubokura & Unknown \\
\hline 37 & Y. pseudotuberculosis & + & - & - & Nielson & M. Tsubokura & Unknown \\
\hline 38 & Y. enterocolitica & - & + & + & M170-1 & K. Kaneko & Large red-backed mouse \\
\hline 39 & $Y$, enterocolitica & - & + & + & M1562-1 & K. Kaneko & Large red-backed mouse \\
\hline 40 & Y. enterocolitica & - & + & + & SD2182-1 & K. Kaneko & Large red-backed mouse \\
\hline 41 & Y. enterocolitica & - & + & + & SD2188-1 & K. Kaneko & Large red-backed mouse \\
\hline 42 & Y. enterocolitica & - & + & + & F38-1 & K. Kaneko & Fox \\
\hline 43 & $Y$. enterocolitica & - & + & + & M134-9 & K. Kaneko & Brown rat \\
\hline 44 & Y. enterocolitica & - & + & + & M694-3 & K. Kaneko & Brown rat \\
\hline 45 & $Y$. enterocolitica & - & + & + & S1044-4 & K. Kaneko & Brown rat \\
\hline 46 & Y. enterocolitica & - & + & + & S1784-11 & K. Kaneko & Brown rat \\
\hline 47 & $Y$. enterocolitica & - & + & + & M1949-1 & K. Kaneko & Brown rat \\
\hline 48 & Y. enterocolitica & - & + & + & ZM235-9 & K. Kaneko & Brown rat \\
\hline 49 & Y. enterocolitica & - & + & + & ZM389-9 & K. Kaneko & Brown rat \\
\hline 50 & Y. enterocolitica & - & + & + & ZM544-4 & K. Kaneko & Brown rat \\
\hline 51 & Y. enterocolitica & - & + & + & ZM734-1 & K. Kaneko & Brown rat \\
\hline 52 & Y. enterocolitica & - & - & + & SD1416-11 & K. Kaneko & Brown rat \\
\hline
\end{tabular}

${ }^{\text {a }}$ Rhamnose and sucrose reactions, 3 days at $22^{\circ} \mathrm{C}$; lecithinase reaction, 2 days at $22^{\circ} \mathrm{C}$.

Loeffler methylene blue. The presence and location of flagella were determined by using Leifson stain. The Gram reaction was determined by the Hucker modification of the Gram stain. The staining reagents and methods used were those described by Paik and Suggs
(24). Fifteen characters involving colony size, shape (elevation and edge), and density were determined from cultures grown on Trypticase soy agar (BBL). Seventeen pigment formation characters were recorded from observations of growth on heart infusion agar 
(Difco Laboratories) containing $0.2 \%$ (wt/vol) DLphenylalanine. The morphological characters were coded as described by Colwell (10).

The abilities of the bacteria to utilize single carbon sources for growth were tested by the methods of Véron (35). The carbon sources tested were acetic acid, $N$-acetyl glucosamine, L-alanine, amidol, Lasparatic acid, $n$-butyl alcohol, $n$-butyric acid, $n$-caproic acid, $n$-caprylic acid, citric acid, L-citrulline, Lcysteine, ethyl alcohol, D-fucose, gluconate, Dglucosamine, D-glucose, L-glutamic acid, DL-glyceric acid, glycine, L-histidine, isobutyric acid, L-isoleucine, isopropyl alcohol, isovaleric acid, $\alpha$-ketoglutaric acid, DL-lactic acid, L-leucine, D-malic acid, L-methionine, methyl alcohol, mucic acid, melezitose, nicotinic acid, oxalic acid, phenol, L-phenylalanine, L-proline, propionic acid, propylene glycol, pyruvic acid, Dribose, L-serine, succinic acid, L-threonine, L-thyrosine, L-tartaric acid, L-tryptophane, $n$-valeric acid, valine, and urea.

Growth at pH 4, 7, and 9 was examined on nutrient agar (Difco) in which the $\mathrm{pH}$ was adjusted with trisaminomethane and citrate phosphate buffer after autoclaving. Tests for growth were made in or on the following media: nutrient broth containing $7.0 \%$ (wt/ vol) $\mathrm{NaCl}$; MacConkey agar (Eiken); Salmonella-shigella agar (Eiken); KCN broth; nutrient broth (Difco) containing $0.2 \%$ (wt/vol) 2,3,5-triphenyltetrazolium chloride; and nutrient agar (Difco) containing $1.0 \%$ ox bile (Oxoid) and $0.032 \%$ potassium tartrate. The ability to grow at 0 and $42^{\circ} \mathrm{C}$ was determined in nutrient broth (Difco).

Antibiotic susceptibilities were determined on heart infusion agar (Difco) containing one of the following antibiotics: penicillin $(10 \mathrm{U} / \mathrm{ml})$, dihydrostreptomycin (2.5 $\mu \mathrm{g} / \mathrm{ml})$, chloramphenicol $(2.5 \mu \mathrm{g} / \mathrm{ml})$, erythromycin $(30 \mu \mathrm{g} / \mathrm{ml})$, kanamycin $(2.5 \mu \mathrm{g} / \mathrm{ml})$, chlortetracycline $(90 \mu \mathrm{g} / \mathrm{ml})$, terramycin $(2.5 \mu \mathrm{g} / \mathrm{ml})$, and tetracycline $(2.5 \mu \mathrm{g} / \mathrm{ml})$.

Production of acid from carbohydrates was detected in peptone water (Difco) containing $0.002 \%(\mathrm{wt} / \mathrm{vol})$ bromthymol blue and $1 \%$ (wt/vol) filter- or heatsterilized carbohydrate. Acid formation was scored after $24 \mathrm{~h}$ and 3 days. The following carbohydrates were tested: adonitol, arabinose, arbutin, cellobiose, dextran, dulcitol, erythritol, esculin, fructose, galactose, glycerin, glycogen, inositol, inulin, maltose, mannitol, mannose, melibiose, $\alpha$-methyl glucoside, raffinose, rhamnose, salicin, sorbitol, sorbose, starch, sucrose, trehalose, and xylose.

The following tests were performed by the methods described by Cowan and Steel (11). Hemolysis was detected on heart infusion agar (Difco) containing $2 \%$ washed sheep erythrocytes. To determine gelatin liquefaction, stabs in nutrient broth (Difco) containing $12 \%(\mathrm{wt} / \mathrm{vol})$ gelatin were observed for 10 days. Other characters determined included: the mode of lactose metabolism by means of the oxidation-fermentation medium of Hugh and Leifson; production of dextran and levan on nutrient agar (Difco) containing 5\% (wt) vol) sucrose; methyl red and Voges-Proskauer reactions in methy red-Voges-Proskauer broth (Eiken); oxidase by the method of Kovacs; catalase activity (addition of 3\% hydrogen peroxide to growth on heart infusion agar [Difco]); phosphatase production by the method of Baird-Parker; and reduction of nitrate and nitrite (determined in peptone water [Difco] containing $0.1 \%$ potassium nitrate or potassium nitrite). Also tested were the following: reactions in purple milk; hydrolysis on skim milk agar made from heart infusion agar (Difco) containing $1 \%$ skim milk; ammonia production from Trypticase peptone water (BBL); hydrogen sulfide production on triple sugar iron agar (Eiken); urease production on Christensen urease agar (BBL); indole production (determined in lysine-indolemotility medium [Nissui] by using Kovac reagent); hydrolysis of Tweens $20,40,60$, and 80 on Sierra medium; citrate utilization on Simmons medium; phenylalanine deaminase production on phenylalanine agar (Difco); production of decarboxylases for Llysine, L-ornithine, L-arginine, and L-glutamic acid in Møller medium; arginine hydrolysis on arginine medium; esculin hydrolysis on nutrient agar (Difco) containing $0.1 \%$ ferric citrate and $0.1 \%$ esculin; deoxyribonuclease production on deoxyribonuclease medium (BBL); utilization of the organic acids of D-tartrate, mucate, and citrate on the medium of Kauffmann and Petersen; lecithinase production on heart infusion agar (Difco) containing $0.5 \%$ egg yolk; oxidation of gluconate in gluconate broth and hippurate hydrolysis on hippurate agar; and decomposition of tyrosine and xanthine on tyrosine and xanthine agars. The $o$-nitrophenyl- $\beta$-D-galactopyranoside test was performed with $o$-nitrophenyl- $\beta$-D-galactopyranoside broth.

Acetoin formation on nutrient broth containing $0.5 \%$ (vol/vol) 2,3-butyleneglycol was also determined by using the Voges-Proskauer reagent. The production of indole pyruvic acid from tryptophane was determined as described previously (29). The production of lipase

TABLE 2. Characters for which all 52 strains were positive at both 37 and $22^{\circ} \mathrm{C}$

Cell shape straight, coccobacillary, round-ended, tapered $^{a}$

Gram strain reaction (negative)

Cell arrangement (single cells) ${ }^{a}$

Colony size $(<2 \mathrm{~mm})$

Colony elevation (convex)

Colony edge (entire)

Density of colony (translucent)

Pigment formation (off-white to gray)

Utilization of glucose $\mathrm{e}^{b}$

Susceptibility to chlortetracycline

Growth at $\mathrm{pH} 7$

Grown on MacConkey agar

Acid from:

Fructose

Galactose $^{a}$

Glycerin

Mannitol

Mannose

Trehalose

Production of:

Urease

Catalase

Acetoin from 2,3-butyleneglycol

Reduction of nitrate ${ }^{a}$

${ }^{a}$ All 52 strains were positive only at $37^{\circ} \mathrm{C}$.

${ }^{b}$ All 52 strains were positive only at $22^{\circ} \mathrm{C}$. 
TABLE 3. Characteristics for which all 52 strains were negative at both 37 and $22^{\circ} \mathrm{C}$

\begin{tabular}{|c|c|}
\hline 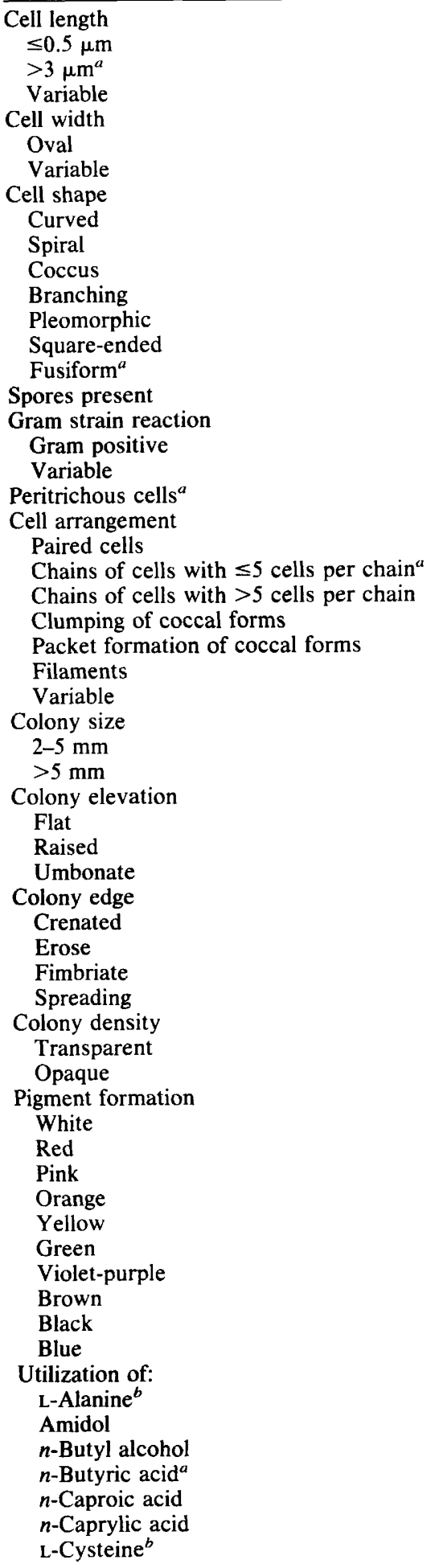 & 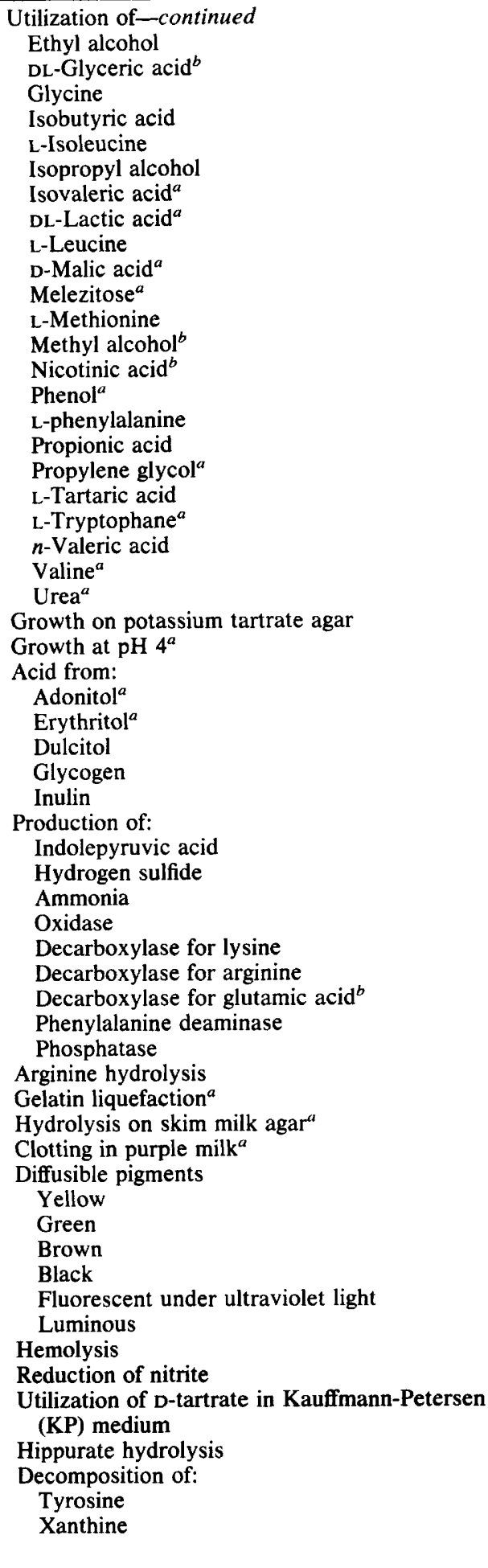 \\
\hline
\end{tabular}

${ }^{a}$ All 52 strains were negative only at $37^{\circ} \mathrm{C}$.

${ }^{b}$ All 52 strains were negative only at $22^{\circ} \mathrm{C}$. 
TABLE 4. Characters for which the 52 strains gave different results at $37^{\circ} \mathrm{C}$

\begin{tabular}{|c|c|c|}
\hline Character & $\begin{array}{l}\text { No. of strains } \\
\text { positive }\end{array}$ & Strain(s) that gave the less common result \\
\hline Utilization of D-glucosamine & 51 & 1 \\
\hline Acid from arabinose & 51 & 35 \\
\hline Growth on agar containing $1 \%$ ox bile & 51 & 4 \\
\hline$o$-Nitrophenyl- $\beta$-D-galactopyranoside & 51 & 1 \\
\hline \multicolumn{3}{|l|}{ Utilization of: } \\
\hline D-Glucose & 50 & 1,35 \\
\hline$N$-Acetyl glucosamine & 50 & 1,14 \\
\hline Methyl red reaction & 50 & 31,35 \\
\hline Growth on salmonella-shigella agar & 50 & 3,35 \\
\hline Growth at $0^{\circ} \mathrm{C}$ & 50 & 4,46 \\
\hline \multicolumn{3}{|l|}{ Acid from: } \\
\hline Dextran & 49 & $11,13,32$ \\
\hline Maltose & 49 & $1,6,7$ \\
\hline Xylose & 47 & $1,6-8,52$ \\
\hline Ornithine decarboxylase & 45 & $31-37$ \\
\hline \multicolumn{3}{|l|}{ Acid from: } \\
\hline Arbutin & 44 & $1,4-8,16,52$ \\
\hline Sorbitol & 44 & $26,31-37$ \\
\hline Utilization of D-ribose & 43 & $1,31-37,50$ \\
\hline Acid from sorbose & 42 & $1,16,17,31-37$ \\
\hline \multicolumn{3}{|l|}{ Utilization of: } \\
\hline Gluconate & 41 & $1,5-7,16,17,22,29,33,36,52$ \\
\hline Pyruvic acid & 40 & $1,25,27-29,32-34,36,37,44,48$ \\
\hline Susceptibility to kanamycin & 40 & $1,2,5-8,11,17,23,35,39,52$ \\
\hline Utilization of $\mathbf{L}$-histidine & 39 & $5-8,19,28-30,32-34,36,37$ \\
\hline Acid in purple milk & 39 & $1,6,7,11,13,31-37,46$ \\
\hline Acid from cellobiose & 38 & $11,13,19,24,25,31-38,40$ \\
\hline Utilization of acetic acid & 37 & $1,25-27,30,31,33-37,40,43,44,52$ \\
\hline Acid from salicin & 36 & $4-8,19,20,22-26,28-30,52$ \\
\hline Indole production & 34 & $1,6,7,16,17,19,20,22,23,28,30,31,33-37,52$ \\
\hline Susceptibility to erythromycin & 34 & $2,9-11,13,19-30,51$ \\
\hline Cell width (slender) & 34 & $2,3,5-9,16,19,31,33,36,38,46,48,49,51,52$ \\
\hline Esculin hydrolysis & 33 & $1,4-8,16,17,19,20,22-26,28-30,52$ \\
\hline Cell length $(1.3-3 \mu \mathrm{m})$ & 33 & $2,3,5-9,15,16,19,31,33,36,38,46,48,49,51,52$ \\
\hline Acid from sucrose & 32 & $4,19-37$ \\
\hline Utilization of L-glutamic acid & 31 & $1,8-10,19,20,25-27,29-34,36,37,40,41,45,46$ \\
\hline Susceptibility to tetracycline & 29 & $16-27,29,30,38-40,44-46,48,50,52$ \\
\hline Utilization of L-serine & 26 & $1,2,7,8,15,17,19,24-37,39,40,45,46,50^{a}$ \\
\hline Utilization of citrate in KP medium & 25 & $2,3,9,11,13,15,18,22,23,28-30,38-46,48-51$ \\
\hline Utilization of L-asparatic acid & 24 & $2,4-7,10-18,21,23,24,38,39,42,44,50-52$ \\
\hline Voges-Proskauer reaction & 22 & $2,3,5-8,15,18,38-48,50-52$ \\
\hline Utilization of L-proline & 21 & $1-3,9,11,14,18,21-25,28-31,36,37,43,45,52$ \\
\hline \multicolumn{3}{|l|}{ Acid from: } \\
\hline Esculin & 20 & $2,3,9,10,15,18,38-51$ \\
\hline Inositol & 19 & $2,3,9,10,12,14,15,38,39,41-46,48-51$ \\
\hline Cell length $(0.5-1.2 \mu \mathrm{m})$ & 19 & $2,3,5-9,15,16,19,31,33,36,38,46,48,49,51,52$ \\
\hline Oxidation of lactose & 18 & $2,4,8,17,19,38-50$ \\
\hline Cell width (short) & 18 & $2,3,5-9,16,19,31,33,36,38,46,48,49,51,52$ \\
\hline Utilization of L-threonine & 17 & $1-3,9,12,15,16,20-25,30,31,43,52$ \\
\hline
\end{tabular}

on lipase medium supplemented with corn oil was determined by the method of Vera and Dumoff (34). Reduction of trimethylamine oxide was determined by the method of Wood and Baird (38).

With the exception of the determinations of temperature growth ranges, all tests were done at both 22 and $37^{\circ} \mathrm{C}$.

Numerical analysis. The simple single-linkage method was used for the numerical analysis. The data were coded in binary notation by using 1 for positive and 0 for negative. All characters were assigned equal weight, and the association coefficients between pairs of bacteria were obtained by computation, using the program of Quadling (27). The similarities between pairs of strains were calculated by using the simple matching coefficient, including negative matches in the similarity computation. Pairs of strains were arranged in order of their similarity values by computation. Phenograms were constructed from the computation data by using the method described of Lessel and Holt (21). The unweighted pair group method was used.

G $+C$ content of DNA. The DNAs were extracted 
TABLE 4-Continued

\begin{tabular}{|c|c|c|}
\hline Character & $\begin{array}{l}\text { No. of strains } \\
\text { positive }\end{array}$ & Strain(s) that gave the less common result \\
\hline Acid from rhamnose & 17 & $2,3,9-15,18,31-37$ \\
\hline Lipase of corn oil & 15 & $8,38-51$ \\
\hline Utilization of L-alanine & 14 & $3-5,38-40,42-44,47,49-52$ \\
\hline Susceptibility to dihydrostreptomycin & 14 & $3,9,10,12-14,16,18,31-34,36,37$ \\
\hline \multicolumn{3}{|l|}{ Hydrolysis of: } \\
\hline Tween 60 & 14 & $3,15,38-40,43-51$ \\
\hline Tween 40 & 13 & $3,15,39,40,43-51$ \\
\hline Utilization of $\alpha$-ketoglutaric acid & 12 & $3,10,11,13,16,22,23,28-31,42$ \\
\hline Acid from melibiose & 12 & $3,15-18,31-37$ \\
\hline Utilization of mucic acid & 11 & $3,9,10,12-16,19,22,23$ \\
\hline Growth in $\mathrm{KCN}$ broth & 11 & $3,9,13-15,18,22,23,28,29,46$ \\
\hline Hydrolysis of Tween 80 & 11 & $38-40,42-48,51$ \\
\hline Growth at $\mathrm{pH} 9$ & 10 & $2,9-14,25,38,39$ \\
\hline Growth at $42^{\circ} \mathrm{C}$ & 10 & $38-43,45,46,49,51$ \\
\hline Growth in $7 \% \mathrm{NaCl}$ broth & 9 & $22,23,28,29,38,39,44,46,47$ \\
\hline Susceptibility to penicillin & 8 & $1,31-37$ \\
\hline Lecithinase & 8 & $38,40,42-45,48,51$ \\
\hline Acid from raffinose & 7 & $15-18,20,31,44$ \\
\hline Citrate utilization on Simmons medium & 7 & $3,9,11-14,18$ \\
\hline Utilization of citric acid & 6 & $2,3,9,12,17,18$ \\
\hline Reduction of trimethylamine oxide & 6 & $2,16,17,45,50,51$ \\
\hline Utilization of D-fucose & 5 & $25,26,30,33,37$ \\
\hline Susceptibility to chloramphenicol & 5 & $1,4,31,32,35$ \\
\hline Fermentation of lactose & 5 & $9,20,21,26,27$ \\
\hline Utilization of mucate in KP medium & 4 & $4,10,12,14$ \\
\hline Hydrolysis of Tween 20 & 4 & $3,15,48,51$ \\
\hline \multicolumn{3}{|l|}{ Utilization of: } \\
\hline L-Cysteine & 3 & $11,24,52$ \\
\hline L-Tyrosine & 3 & $22-24$ \\
\hline Nicotinic acid & 3 & $7,13,22$ \\
\hline \multicolumn{3}{|l|}{ Acid from: } \\
\hline$\alpha$-Methyl glucoside & 3 & $3,15,18$ \\
\hline Starch & 3 & $29,30,35$ \\
\hline Utilization of oxalic acid & 2 & 9,12 \\
\hline Glutamic acid decarboxylase & 2 & 39,40 \\
\hline \multicolumn{3}{|l|}{ Utilization of: } \\
\hline L-Citrulline & 1 & 7 \\
\hline DL-Glyceric acid & 1 & 10 \\
\hline Methyl alcohol & 1 & 6 \\
\hline Succinic acid & 1 & 4 \\
\hline Susceptibility to terramycin & 1 & 35 \\
\hline Deoxyribonuclease & 1 & 32 \\
\hline Growth in TTC broth ${ }^{b}$ & 1 & 14 \\
\hline Oxidation of gluconate & 1 & 18 \\
\hline Levan & 1 & 29 \\
\hline Dextran & 1 & 1 \\
\hline
\end{tabular}

${ }^{a}$ These strains were negative.

${ }^{b}$ TTC, 2,3,5-Triphenyltetrazolium chloride.

from three sucrose-negative strains of $Y$. enterocolitica, one rhamnose-negative $Y$. enterocolitica serovar O3 strain, one $Y$. pseudotuberculosis serovar IVA strain, and one Aeromonas salmonicida strain (ATCC 14174) as described by Marmur (22). The guanineplus-cytosine $(\mathrm{G}+\mathrm{C})$ content of each DNA preparation was calculated from the thermal melting point by using the method of Marmur and Doty (23). The thermal melting point was determined with a Hitach model 124 spectrophotometer. The experiment was repeated three times for each of the Yersinia strains.

\section{RESULTS}

Characters of the strains tested. The characters of the strains are listed in Tables 2 through 5. At $37^{\circ} \mathrm{C}, 24$ characters were all positive, 100 were all negative, and there were 86 characters in which one or more of the strains differed (Table 4). At $22^{\circ} \mathrm{C}, 21$ characters were all positive, 86 were all negative, and there were 103 characters in which one or more of the strains differed (Table 5). 
TABLE 5. Characteristics for which the 52 strains gave different results at $22^{\circ} \mathrm{C}$

\begin{tabular}{|c|c|c|}
\hline Character & $\begin{array}{l}\text { No. of strains } \\
\text { positive }\end{array}$ & Strain(s) that gave the less common result \\
\hline \multicolumn{3}{|l|}{ Acid from: } \\
\hline Arabinose & 51 & 35 \\
\hline Maltose & 51 & 1 \\
\hline Reduction of nitrate & 51 & 4 \\
\hline Growth on agar containing $1 \%$ ox bile & 51 & 4 \\
\hline$o$-Nitrophenyl- $\beta$-D-galactopyranoside & 51 & 1 \\
\hline Growth on salmonella-shigella agar & 51 & 35 \\
\hline Cell shape (tapered) & 51 & 4 \\
\hline Cell arrangement (single cells) & 51 & 4 \\
\hline \multicolumn{3}{|l|}{ Utilization of: } \\
\hline$N$-Acetyl glucosamine & 50 & 1,44 \\
\hline D-Glucosamine & 50 & 1,44 \\
\hline Growth at $0^{\circ} \mathrm{C}$ & 50 & 4,46 \\
\hline Methyl red reaction & 48 & $38,40-42$ \\
\hline Utilization of pyruvic acid & 47 & $28,44,46,50,51$ \\
\hline \multicolumn{3}{|l|}{ Acid from: } \\
\hline Dextran & 47 & $24,38-41$ \\
\hline Xylose & 47 & $1,6-8,52$ \\
\hline Galactose & 46 & $6,7,18,33,35,37$ \\
\hline \multicolumn{3}{|l|}{ Utilization of: } \\
\hline L-Glutamic acid & 46 & $1,8,19,21,24,34$ \\
\hline L-Histidine & 45 & $5-8,10,36,37$ \\
\hline Ornithine decarboxylase & 45 & $31-37$ \\
\hline Acid from sorbitol & 44 & $26,31-37$ \\
\hline Utilization of citrate in KP medium & 44 & $1,19-21,24,26,27,47$ \\
\hline Peritrichous cells & 44 & $1,6,7,31-34,52$ \\
\hline Utilization of D-ribose & 42 & $1,31-38,50$ \\
\hline Growth at $\mathrm{pH} 9$ & 42 & $1,4,6-8,17,34,35,37,52$ \\
\hline Acid from sorbose & 41 & $1,16,17,24,31-37$ \\
\hline Utilization of gluconate & 39 & $1,2,5-7,9,11,13,28,32,36,46,52$ \\
\hline Acid from cellobiose & 38 & $11,13,19,24,25,31-38,40$ \\
\hline Cell width (slender) & 37 & $2,6-9,21,22,24,27,32,33,36,45,49,52$ \\
\hline Indole production & 36 & $1,6,7,16,17,22,23,28-31,33,35-37,52$ \\
\hline Acid in purple milk & 36 & $1,6,7,11-13,31-37,46,49,52$ \\
\hline Cell length $(1.3-3 \mu \mathrm{m})$ & 36 & $\begin{array}{l}2,4,8,14,19,21,22,24,27,29,32,33,36,45 \\
\quad 49,52\end{array}$ \\
\hline Acid from arbutin & 35 & $1,4-8,19,20,22-26,28-30,52$ \\
\hline Utilization of $\mathrm{L}$-asparatic acid & 33 & $1,2,5-8,10,11,13,15-21,23,24,35$ \\
\hline Growth in TTC broth ${ }^{a}$ & 33 & $1,3-5,8,11,12,16,17,26,27,31-37,50$ \\
\hline Reduction of trimethylamine oxide & 33 & $4,10-14,19,20,24-27,31-37$ \\
\hline \multicolumn{3}{|l|}{ Acid from: } \\
\hline Sucrose & 32 & $4,19-37$ \\
\hline Salicin & 31 & $4-8,16,17,19-23,25-30,35,37,52$ \\
\hline Esculin hydrolysis & 31 & $1,4-8,16,17,19-30,52$ \\
\hline Utilization of acetic acid & 30 & $1,2,10,26,28,32-36,38-44,46-49,50,52$ \\
\hline Growth in $\mathrm{KCN}$ broth & 29 & $1,2,4-8,19-21,26,27,32-37,41,43,44,51,52$ \\
\hline Growth in $7 \% \mathrm{NaCl}$ broth & 27 & $\begin{array}{l}1-7,16,18,21,24-26,28,31-33,35-37,43,45 \\
51,52\end{array}$ \\
\hline Utilization of L-serine & 26 & $\begin{array}{l}2-4,6,9-14,16,18,21,22,24,25,27,31,33 \\
\quad 34,42-45,48,51^{b}\end{array}$ \\
\hline Susceptibility of tetracycline & 25 & $1-9,15-18,32-37,44-47,49,52$ \\
\hline \multicolumn{3}{|l|}{ Acid from: } \\
\hline Esculin & 24 & $1-3,9,10,12-15,18,38-51$ \\
\hline Inositol & 23 & $2-5,8-15,39,41-46,48-51$ \\
\hline Utilization of L-proline & 23 & $2-5,9-11,15-18,22,28,29,30-37,46$ \\
\hline Voges-Proskauer reaction & 23 & $1-3,5-8,15-18,38-48,50-52$ \\
\hline \multicolumn{3}{|l|}{ Hydrolysis of: } \\
\hline Tween 20 & 22 & $3,15,18,22,23,28-30,38-51$ \\
\hline Tween 40 & 22 & $3,15,18,22,23,28-30,38-51$ \\
\hline Tween 60 & 22 & $3,15,18,22,23,28-30,38-51$ \\
\hline Tween 80 & 22 & $3,15,18,22,23,28-30,38-51$ \\
\hline
\end{tabular}


TABLE 5-Continued

\begin{tabular}{|c|c|c|}
\hline Character & $\begin{array}{l}\text { No. of strains } \\
\text { positive }\end{array}$ & Strain(s) that gave the less common result \\
\hline Oxidation of lactose & 21 & $2,4,5,8,19,20,24-26,38-49$ \\
\hline Acid from rhamnose & 17 & $2,3,9-15,18,31-37$ \\
\hline Oxidation of gluconate & 17 & $3,15,18,38-48,50-52$ \\
\hline Lecithinase & 17 & $3,15,18,38-51$ \\
\hline Lipase of corn oil & 16 & $8,15,38-51$ \\
\hline Cell width (short) & 15 & $2,6-9,21,22,24,27,32,33,36,45,49,52$ \\
\hline Susceptibility to erythromycin & 15 & $1,3,4,6-8,15-18,31,32,35,37,52$ \\
\hline Utilization of citrate on Simmons medium & 14 & $3,9,11-18,31-33,36$ \\
\hline Cell length $(0.5-1.2 \mu \mathrm{m})$ & 14 & $2,8,19,21,22,24,27,29,32,33,36,45,49,52$ \\
\hline Growth at $\mathrm{pH} 4$ & 14 & $2,10,19-21,24-27,29,38,48,49,51$ \\
\hline Utilization of citric acid & 13 & $3,6,9,11-18,20,23$ \\
\hline Clotting in purple milk & 13 & $18,20,21,26,27,38-42,44,47,50$ \\
\hline Utilization of $\mathrm{L}$-threonine & 12 & $2-5,8,9,11,15,16,18,20,22$ \\
\hline Acid from melibiose & 12 & $3,15-18,31-37$ \\
\hline Utilization of mucate in KP medium & 12 & $2-4,9-16,18$ \\
\hline \multicolumn{3}{|l|}{ Utilization of: } \\
\hline Mucic acid & 11 & $2-4,9-15,18$ \\
\hline Urea & 10 & $2,4,9,11,13,18,20-22,24$ \\
\hline Growth at $42^{\circ} \mathrm{C}$ & 10 & $38-43,45,46,49,51$ \\
\hline Utilization of $\alpha$-ketoglutaric acid & 9 & $3,4,6,7,12-14,22,29$ \\
\hline Acid from starch & 9 & $23,30,31,34-36,43,50,51$ \\
\hline \multicolumn{3}{|l|}{ Susceptibility to: } \\
\hline Penicillin & 8 & $1,31-37$ \\
\hline Kanamycin & 8 & $1,9,12,31-33,36,37$ \\
\hline Utilization of oxalic acid & 7 & $3,6,9,13,15,18,23$ \\
\hline \multicolumn{3}{|l|}{ Acid from: } \\
\hline Adonitol & 7 & $19-21,24-27$ \\
\hline \multirow{2}{*}{\multicolumn{3}{|c|}{ Utilization of: }} \\
\hline & & \\
\hline D-Fucose & 5 & $10,11,18,31,32$ \\
\hline$n$-Butyric acid & 4 & $6,18,22,23$ \\
\hline DL-Lactic acid & 3 & $2,9,24$ \\
\hline Succinic acid & 3 & $2,4,8$ \\
\hline Acid from $\alpha$-methyl glucoside & 3 & $3,15,18$ \\
\hline Levan & 3 & $2,13,29$ \\
\hline \multicolumn{3}{|l|}{ Susceptibility to: } \\
\hline Dihydrostreptomycin & 3 & $31,36,37$ \\
\hline Chloramphenicol & 3 & $1,4,35$ \\
\hline Fermentation of lactose & 2 & 21,27 \\
\hline Susceptibility to terramycin & 2 & 1,35 \\
\hline Cell length $(>3 \mu \mathrm{m})$ & 2 & 4,14 \\
\hline Deoxyribonuclease & 2 & 11,14 \\
\hline \multicolumn{3}{|l|}{ Utilization of: } \\
\hline L-Citrulline & 2 & 31,45 \\
\hline Isovaleric acid & 2 & 4,21 \\
\hline D-Malic acid & 2 & 3,39 \\
\hline Propylene glycol & 2 & 4,21 \\
\hline L-Threonine & 2 & 10,31 \\
\hline Valine & 2 & 31,45 \\
\hline Melezitose & 1 & 46 \\
\hline Phenol & 1 & 17 \\
\hline L-Tryptophane & 1 & 35 \\
\hline Gelatin liquefaction & 1 & 18 \\
\hline Acid from erythritol & 1 & 24 \\
\hline Hydrolysis on skim milk agar & 1 & 18 \\
\hline Dextran & 1 & 1 \\
\hline Cell shape (fusiform) & 1 & 4 \\
\hline $\begin{array}{l}\text { Cell arrangement (chains of cells with } \leq 5 \\
\text { cells per chain) }\end{array}$ & 1 & 4 \\
\hline
\end{tabular}

${ }^{a}$ TTC, 2,3,5-Triphenyltetrazolium chloride.

${ }^{b}$ These strains were positive. 


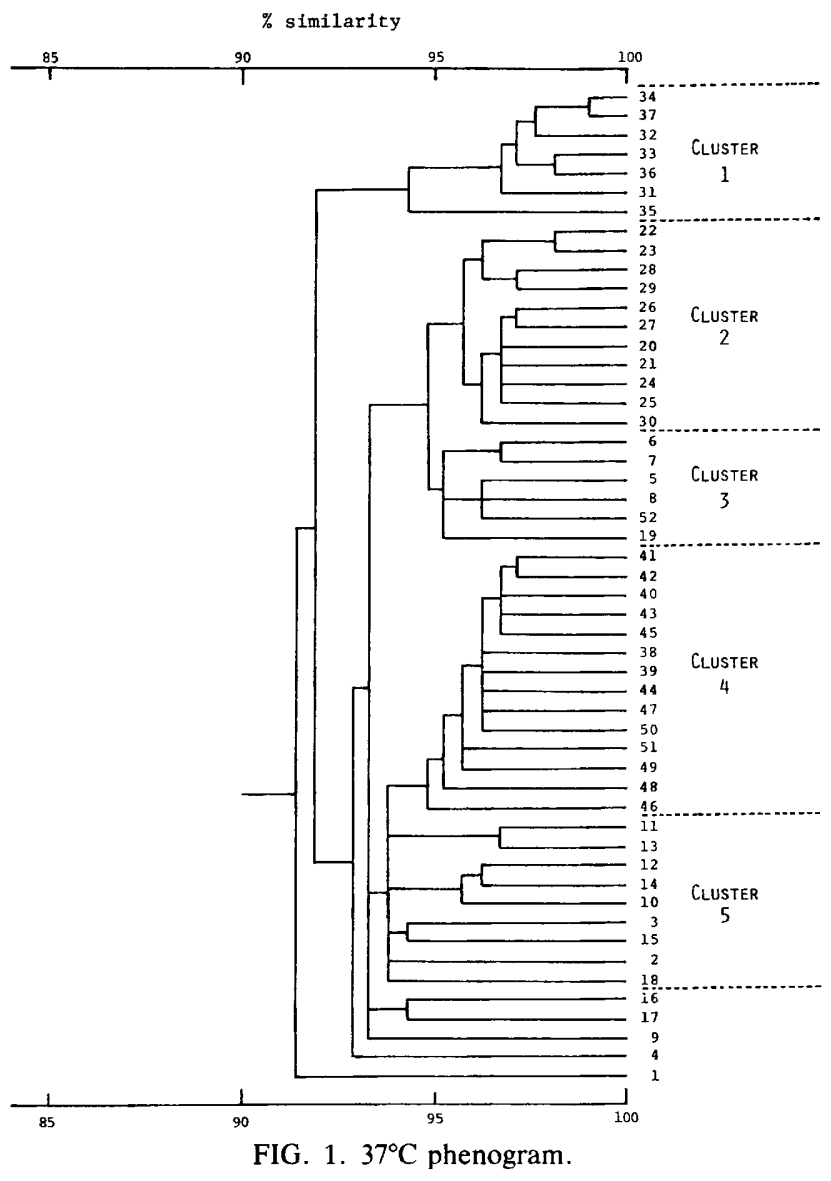

Numerical taxonomy. The phenograms constructed from the computation data are shown in Fig. 1 and 2.

At a similarity level of $93 \%$, the $37^{\circ} \mathrm{C}$ matrix distinguished five clusters (Fig. 1). All seven strains in cluster 1 belonged to $Y$. pseudotuberculosis. The 11 strains in cluster 2 were sucrose, rhamnose, and lecithinase negative. Five of the six strains in cluster 3 were sucrose positive and rhamnose and lecithinase negative; the other strain in cluster 3 was sucrose, rhamnose, and lecithinase negative. A total of 14 of the strains in cluster 4 were sucrose positive, rhamnose negative, and lecithinase positive. Six of the nine strains in cluster 5 were sucrose and rhamnose positive and lecithinase negative, and the other three strains in cluster 5 were sucrose, rhamnose, and lecithinase positive. Five strains (strains 1, 4, 9, 16, and 17) were not clustered.

At a similarity level of $92 \%$, the $22^{\circ} \mathrm{C}$ matrix distinguished six clusters (Fig. 2). The strains in clusters $1,2,3$, and 6 were found in clusters 4,2 , 3 , and 1 of the $37^{\circ} \mathrm{C}$ matrix, respectively. The strains in clusters 4 and 5 were in cluster 5 of the $37^{\circ} \mathrm{C}$ matrix. The three strains in cluster 4 were sucrose, rhamnose, and lecithinase positive, and seven strains in cluster 5 were sucrose and rhamnose positive and lecithinase negative. Three of the five unclustered strains of the $37^{\circ} \mathrm{C}$ matrix were clustered in the $22^{\circ} \mathrm{C}$ matrix; two strains (strains 16 and 17 ) were in cluster 3 , and one strain (strain 9) was in cluster 5. Two strains (strains 1 and 4) were not clustered.

The biochemical characters which differentiated clusters 1 through 5 of the $22^{\circ} \mathrm{C}$ phenogram are shown in Table 6 . The 14 strains in cluster 1 were rhamnose negative and lecithinase and sucrose positive; the 12 strains in cluster 2 were rhamnose, lecithinase, and sucrose negative; the 7 strains in cluster 3 were rhamnose and lecithinase negative and sucrose positive; the 3 strains in cluster 4 were rhamnose, lecithinase, and sucrose positive; and the 7 strains in cluster 5 were rhamnose positive, lecithinase negative, and sucrose positive.

$G+C$ contents of the sucrose-negative strains of $Y$. enterocolitica. Table 7 shows the $\mathrm{G}+\mathrm{C}$ contents of the DNAs of the sucrose-negative 


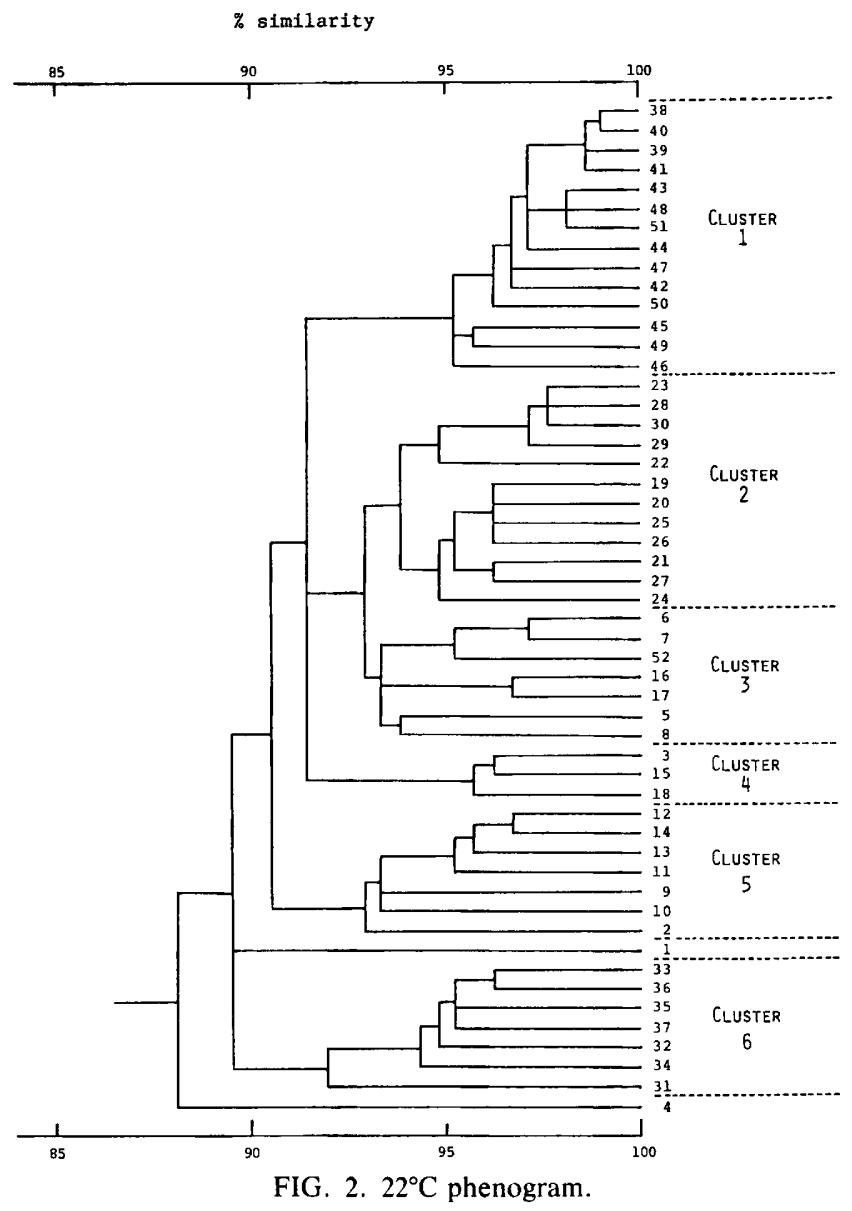

strains of $Y$. enterocolitica isolated from rodents; all of the $\mathrm{G}+\mathrm{C}$ values were about 49 mol\%. The G+C content of the DNA of the $A$. salmonicida strain which was used as a control was $57.2 \mathrm{~mol} \%$.

\section{DISCUSSION}

In our study, the typical rhamose-negative $Y$. enterocolitica strains were divided into two clusters, lecithinase-positive and lecithinase-negative strains (Fig. 1 and 2). Lecithinase-positive strains have been isolated frequently from rodents in Japan $(15,17)$ and Europe $(1,18,19)$. Lecithinase-negative strains, which are recognized as human enteric pathogens, have seldom been detected in these animals (15). The reservoirs of the human pathogens are pigs $(13,25$, $26,31,32,37)$ and dogs (16). Thus, lecithinasenegative and lecithinase-positive strains of $Y$. enterocolitica seem to have different host species. Wauters (36) placed the lecithinase-positive and lecithinase-negative strains in different biovars: the lecithinase-positive strains in biovar
1 and the lecithinase-negative strains in biovars 2 through 5. In our study, biovar 1 of Wauters belonged to a cluster different from that of the lecithinase-negative biovars (Fig. 1 and 2). These findings support the suggestion that the rhamnose-negative strains of $Y$. enterocolitica comprise two taxonomic subgroups.

The rhamose- and lecithinase-negative strains of cluster 3 (Fig. 2) were biochemically heterogeneous (Table 2). Sakazaki et al. (28) distinguished two phenotypic clusters among such strains. Therefore, it is possible that there is a subgroup among the rhamnose- and lecithinasenegative $Y$. enterocolitica strains.

Our results support the suggestion that the sucrose-negative strains of $Y$. enterocolitica do indeed belong to the genus Yersinia. The $\mathrm{G}+\mathrm{C}$ contents of the DNAs of these strains coincide with those of $Y$. enterocolitica serovar $\mathrm{O} 3$ and $Y$. pseudotuberculosis serovar IVA. Our sucrosenegative isolates were clustered differently from the typical rhamnose-negative strains of $Y$. enterocolitica. This is in accord with the results of 
TABLE 6. Biochemical differentiation of $Y$. enterocolitica clusters obtained by using data from cultures incubated at $22^{\circ} \mathrm{C}$

\begin{tabular}{|c|c|c|c|c|c|}
\hline \multirow[b]{2}{*}{ Test } & \multicolumn{5}{|c|}{ Reaction of: } \\
\hline & $\begin{array}{l}\text { Cluster } 1 \\
(n=14)\end{array}$ & $\begin{array}{l}\text { Cluster } 2 \\
(n=12)\end{array}$ & $\begin{array}{c}\text { Cluster } 3 \\
(n=7)\end{array}$ & $\begin{array}{c}\text { Cluster } 4 \\
(n=3)\end{array}$ & $\begin{array}{c}\text { Cluster } 5 \\
(n=7)\end{array}$ \\
\hline \multicolumn{6}{|l|}{ Acid from: } \\
\hline Rhamnose & $-{ }^{a}$ & - & - & + & + \\
\hline$\alpha$-Methyl glucoside & - & - & - & + & - \\
\hline Sucrose & + & - & + & + & + \\
\hline Raffinose & - & - & $-(5)^{b}$ & + & - \\
\hline Melibiose & - & - & $-(5)$ & + & - \\
\hline Trehalose & + & + & + & + & + \\
\hline Lecithinase & + & - & - & + & - \\
\hline Ornithine decarboxylase & + & + & + & + & + \\
\hline Nitrate reduction & + & + & + & + & + \\
\hline
\end{tabular}

${ }^{a}$ No number indicates that all strains showed the homologous reaction.

$b$ The numbers in parentheses indicate the number of strains that showed the reaction.

Bercovier et al. (4), who proposed the new name Yersinia kristensenii for sucrose-negative strains. The fact that one sucrose-negative strain was clustered together with $Y$. enterocolitica sensu stricto strains at $37^{\circ} \mathrm{C}$ may have been due to some genetic overlap between $Y$. kristensenii and $Y$. enterocolitica, as revealed by the DNADNA hybridization data of Bercovier et al. (4).

The frequency of recovery of atypical rhamnose-positive strains from freshwater ecosystems $(7,33)$ is apparently high. In our study, these strains were divided into the following groups: (i) the rhamnose-positive and raffinoseand melibiose-negative group and (ii) the rhamnose-, raffinose-, and melibiose-positive group (clusters 4 and 5). This is in accord with the DNA-DNA hybridization data $(6,7,33)$. The new name Yersinia frederiksenii was proposed by Ursing et al. (33) for the former group, and for the latter group the name Yersinia intermedia

TABLE 7. G+C contents of the DNAs of sucrosenegative $Y$. enterocolitica strains

\begin{tabular}{lcl}
\hline \multicolumn{1}{c}{ Organism } & $\begin{array}{c}\text { Strain } \\
\text { no. }\end{array}$ & $\mathrm{G}+\mathrm{C}$ content $(\mathrm{mol} \%)^{a}$ \\
\hline $\begin{array}{l}\text { Sucrose-negative } \\
\quad \text { Y. enterocolitica }\end{array}$ & 20 & $49.0,49.0,49.6^{b}$ \\
$\begin{array}{c}\text { Sucrose-negative } \\
Y . \text { enterocolitica }\end{array}$ & 25 & $48.2,48.2,49.0$ \\
$\begin{array}{c}\text { Sucrose-negative } \\
\text { Y. enterocolitica }\end{array}$ & 29 & $49.3,49.3,49.0$ \\
$\begin{array}{l}Y . \text { enterocolitica } \\
\text { serovar O3 }\end{array}$ & 6 & $48.5,48.5,48.2$ \\
$\begin{array}{l}Y . \text { pseudotuberculosis } \\
\text { serovar IVA }\end{array}$ & 32 & $49.0,49.0,49.3$ \\
$\begin{array}{c}\text { A. salmonicida ATCC } \\
\text { 14174 }\end{array}$ & 57.2 \\
\hline
\end{tabular}

${ }^{a}$ Calculated from thermal melting temperatures.

${ }^{b}$ Results of three experiments. was offered by Brenner et al. (7).

All of the $Y$. pseudotuberculosis strains were in one cluster according to either the $22^{\circ} \mathrm{C}$ phenogram or the $37^{\circ} \mathrm{C}$ phenogram.

Harvey and Pickett (12) reported that a $30^{\circ} \mathrm{C}$ $Y$. enterocolitica matrix differentiated more clusters than a $35^{\circ} \mathrm{C}$ matrix because the enzymes of the organisms are more active at the lower temperature. In our study, the lecithinase activities of the positive strains tested were generally weak, and six of the strains were negative in this character at $37^{\circ} \mathrm{C}$. Our study also showed that more clusters were delineated at the lower temperature and that the biochemical characters of the strains within each cluster were more homogenous at $22^{\circ} \mathrm{C}$. Therefore, we prefer the five clusters derived from the $22^{\circ} \mathrm{C}$ data to the four clusters derived from the $37^{\circ} \mathrm{C}$ data in our study. Furthermore, we apply five biovars to the five clusters as follows: (i) biovar 1 , the rhamnosenegative and lecithinase- and sucrose-positive strains; (ii) biovar 2, the rhamnose-, lecithinase-, and sucrose-negative strains; (iii) biovar 3 , the rhamnose- and lecithinase-negative, sucrosepositive strains; (iv) biovar 4 , the rhamnose-, lecithinase-, and sucrose-positive strains; and (v) biovar 5, the rhamnose-positive, lecithinasenegative, and sucrose-positive strains.

Two reference strains (rhamnose- and lecithinase-negative, sucrose-positive strain 1 and rhamnose-, lecithinase-, and sucrose-negative strain 4) were not clustered in our study. These strains differed from the other strains with respect to utilization of single carbon sources and antibiotic susceptibilities. The fact that these two strains did not cluster may be due to their sources and place of isolation, small rodents in Japan. Therefore, it appears that taxonomic studies on strains collected from diverse origins are necessary. 


\section{ACKNOWLEDGMENTS}

We thank T. Seya, I. Furuta, K. Fukawa, and K. Nakano for technical assistance. We also thank T. Kimura, Department of Food Science and Technology, Faculty of Fisheries, Hokkaido University, Hakodate Branch, for help in determining the thermal denaturation temperatures of DNAs. All computations were done in the Hokkaido University Computing Center.

This work was supported in part by a grant-in-aid for special project research from the Ministry of Education, Science and Culture, Japan.

\section{REPRINT REQUESTS}

Address reprint requests to: Ken-ichi Kaneko, Department of Veterinary Public Health, Faculty of Veterinary Medicine, Hokkaido University, Sapporo 060, Japan.

\section{LITERATURE CITED}

1. Aldová, E., and D. Lim. 1974. Yersinia enterocolitica in small rodents. I. Pilot study in two wildlife areas. Zentralbl. Bakteriol. Parasitenkd. Infektionskr. Hyg. Abt. 1 Orig. Reihe A 226:491-496.

2. Bercovier, H., J. Brault, N. Barre, M. Treignier, J. M. Alonso, and H. H. Mollaret. 1978. Biochemical, serologi$\mathrm{cal}$ and phage typing characteristics of 459 Yersinia strains isolated from a terrestrial ecosystem. Curr. Microbiol. 1:353-357.

3. Bercovier, H., D. J. Brenner, J. Ursing, A. G. Steigerwalt, G. R. Fanning, J. M. Alonso, G. P. Carter, and H. H. Mollaret. 1980. Characterization of Yersinia enterocolitica sensu stricto. Curr. Microbiol. 4:201-206.

4. Bercovier, H., J. Ursing, D. J. Brenner, A. G. Steigerwalt, G. R. Fanning, G. P. Carter, and H. H. Mollaret. 1980. Yersinia kristensenii: a new species of Enterobacteriaceat composed of sucrose-negative strains (formerly called atypical Yersinia enterocolitica or Yersinia enterocolitica like). Curr. Microbiol. 4:219-224.

5. Bottone, E. J. 1978. Atypical Yersinia enterocolitica: clinical and epidemiological parameters. J. Clin. Microbiol. 7:562-567.

6. Brenner, D. J. 1979. Speciation in Yersinia. Contrib. Microbiol. Immunol. 5:33-43.

7. Brenner, D. J., H. Bercovier, J. Ursing, J. M. Alonso, A. G. Steigerwalt, G. R. Fanning, G. P. Carter, and H. H. Mollaret. 1980. Yersinia intermedia: a new species of Enterobacteriaceae composed of rhamnose-positive, melibiose-positive, raffinose-positive strains (formerly called Yersinia enterocolitica or Yersinia enterocolitica-like). Curr. Microbiol. 4:207-212.

8. Brenner, D. J., A. G. Steigerwalt, D. P. Falcao, R. E. Weaver, and G. R. Fanning. 1976. Characterization of Yersinia enterocolitica and Yersinia pseudotuberculosis by deoxyribonucleic acid hybridization and by biochemical reaction. Int. J. Syst. Bacteriol. 26:180-194.

9. Caprioli, T., A. J. Drapeau, and S. Kasatiya. 1978. Yersinia enterocolitica: serotypes and biotypes isolated from humans and the environment in Quebec, Canada. J. Clin. Microbiol. 8:7-11

10. Colwell, R. R. 1970. Collecting the data, p. 4-21. In W. R. Lockhart and J. Liston (ed.), Methods for numerical taxonomy. American Society for Microbiology, Washington, D.C.

11. Cowan, S. T., and K. J. Steel. 1974. Identification of medical bacteria. Cambridge University Press, London.

12. Harvey, S., and M. J. Pickett. 1980. Comparison of adansonian analysis and deoxyribonucleic acid hybridization results in the taxonomy of Yersinia enterocolitica. Int. J. Syst. Bacteriol. 30:86-102.

13. Hurvell, B., V. Glatthard, and E. Thal. 1979. Isolation of Yersinia enterocolitica from swine at an abattoir in Sweden. Contrib. Microbiol. Immunol. 5:243-248.
14. Kaneko, K., S. Hamada, Y. Kasai, and N. Hashimoto. 1979. Smoldering epidemic of Yersinia pseudotuberculosis in barn rats. Appl. Environ. Microbiol. 37:1-3.

15. Kaneko, K., S. Hamada, Y. Kasai, and E. Kato. 1978. Occurrence of Yersinia enterocolitica in house rats. Appl. Environ. Microbiol. 36:314-318.

16. Kaneko, K., S. Hamada, and E. Kato. 1977. Occurrence of Yersinia enterocolitica in dogs. Jpn. J. Vet. Sci. 39:407414.

17. Kaneko, K., and N. Hashimoto. 1981. Occurrence of Yersinia enterocolitica in wild animals. Appl. Environ. Microbiol. 41:635-638.

18. Kapperud, G. 1975 . Yersinia enterocolitica in small rodents from Norway, Sweden and Finland. Acta Pathol. Microbiol. Scand. Sect. B 83:335-342.

19. Kapperud, G. 1977. Yersinia enterocolitica and Yersinialike microbes isolated from mammals and water in Norway and Denmark. Acta Pathol. Microbiol. Scand. Sect. B 85:129-135.

20. Kapperud, G., T. Bergan, and J. Lassen. 1981. Numerica taxonomy of Yersinia enterocolitica and Yersinia enterocolitica-like bacteria. Int. J. Syst. Bacteriol. 31:401-419.

21. Lessel, E. F., and J. G. Holt. 1970. Presenting and interpreting the results, p. 50-58. In W. R. Lockhart and J. Liston (ed.), Methods for numerical taxonomy. American Society for Microbiology, Washington, D.C.

22. Marmur, J. 1961. A procedure for the isolation of deoxyribonucleic acid from microorganisms. J. Mol. Biol. 3:208218

23. Marmur, J., and P. Doty. 1962. Determination of the base composition of deoxyribonucleic acid from its thermal denaturation temperature. J. Mol. Biol. 5:109-118.

24. Paik, G., and N. T. Suggs. 1974. Reagents, stains and miscellaneous test procedures, p. 930-950. In E. H. Lennette, E. H. Spaulding, and J. P. Truant (ed.), Manual of clinical microbiology, 2nd ed. American Society for Microbiology, Washington, D.C.

25. Pedersen, D. B. 1979. Occurrence of Yersinia enterocolitica in the throat of swine. Contrib. Microbiol. Immunol 5:253-256.

26. Pedersen, K. B., and S. Winblad. 1979. Studies on Yersinia enterocolitica isolated from swine and dogs. Acta Pathol. Microbiol. Scand. Sect. B 87:137-140.

27. Quadling, D. 1970. Analyzing the data, p. 34-49. In W. R. Lockhart and J. Liston (ed.), Methods for numerical taxonomy. American Society for Microbiology, Washington, D.C.

28. Sakazaki, R., K. Tamura, and T. Shimada. 1979. Numerical classification of Yersinia enterocolitica and relationship between its subdivision and pathogenicity. Contrib. Microbiol. Immunol. 5:23-32.

29. Singer, J., and B. E. Volcani. 1955. An improved ferric chloride test for differentiating Proteus Providence group from other Enterobacteriaceae. J. Bacteriol. 69:303-306.

30. Stevens, M., and N. S. Mair. 1973. A numerical taxonomic study of Yersinia enterocolitica strains. Contrib. Microbiol. Immunol. 2:17-22.

31. Tsubokura, M., T. Fukuda, K. Otsuki, M. Kubota, K. Itagaki, K. Yamaoka, and M. Wakatsuki. 1976. Studies on Yersinia enterocolitica. II. Relationship between detection from swine and seasonal incidence, and regional distribution of the organism. Jpn. J. Vet. Sci. 38:1-6.

32. Tsubokura, M., K. Otsuki, and K. Itagaki. 1973. Studies on Yersinia enterocolitica. I. Isolation of $Y$. enterocolitica from swine. Jpn. J. Vet. Sci. 35:419-424.

33. Ursing, J., D. J. Brenner, H. Bercovier, G. R. Fanning, A. G. Steigerwalt, J. Brault, and H. H. Mollaret. 1980 Yersinia frederiksenii: a new species of Enterobacteriaceae composed of rhamnose-positive strains (formerly called atypical Yersinia enterocolitica or Yersinia enterocolitica-like). Curr. Microbiol. 4:213-218.

34. Vera, H. G., and M. Dumoff. 1974. Culture media, p. 881929. In E. H. Lennette, E. H. Spaulding, and J. P. Truant (ed.), Manual of clinical microbiology, 2nd ed. American Society for Microbiology, Washington, D.C. 
35. Véron, M. 1975. Nutrition et taxonomie des Enterobacteriaceae et bactéries voisines. I. Méthods d'étude des auzanogrammes. Ann. Microbiol. 126A:267-273.

36. Wauters, G. 1973. Correlation between ecology, biochemical behaviour and antigenic properties of Yersinia enterocolitica. Contrib. Microbiol. Immunol. 2:38-41.
37. Wauters, G. 1979. Carriage of Yersinia enterocolitica serotype 3 by pigs as a source of human infection. Contrib. Microbiol. Immunol. 5:249-252.

38. Wood, A. J., and E. A. Baird. 1943. Reduction of trimethylamine oxide by bacteria. I. The Enterobacteriaceae. J. Fish. Res. Board Can. 6:194-201. 